\title{
Relative expression of mRNAs related to cavitation process in bovine embryos produced in vivo and in vitro
}

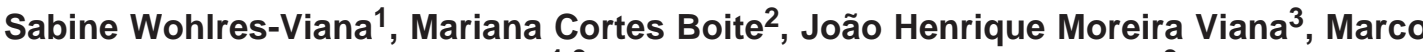 Antonio Machado ${ }^{1,3}$, Luiz Sérgio de Almeida Camargo ${ }^{3}$}

\footnotetext{
1 Universidade Federal de Juiz de Fora.

2 Universidade Federal Fluminense.

${ }^{3}$ Embrapa Gado de Leite.
}

\begin{abstract}
The objectives of this work were to identify and to evaluate possible differences on gene expression of aquaporins and $\mathrm{Na} / \mathrm{K}$-ATPases transcripts between embryos in vivo and in vitro produced. For each group, 15 blastocysts distributed in three pools were used for RNA extraction followed by amplification and reverse transcription. The resulting cDNAs were submitted to Real-Time PCR, using the GAPDH gene as endogenous control. It was not possible to identify AQP1 transcripts. Relative expression of AQP3 $(1.33 \pm 0.78)$ and AQP11 (2.00 \pm 1.42$)$ were not different in blastocysts in vitro and in vivo produced. $\mathrm{Na} / \mathrm{K}$-ATPase $\alpha 1$ gene $(2.25 \pm 1.07)$ was overregulated whereas $\mathrm{Na} / \mathrm{K}$-ATPase $\beta 2$ transcripts $(0.40 \pm 0.30)$ did not differ among blastocysts produced in vitro from those produced in vivo. Transcripts for gene AQP1 are not present in bovine blastocysts. In vitro culture system does not alter expression of genes AQP3, AQP11 and $\mathrm{Na} / \mathrm{K}$-ATPase $\beta 2$ genes, however, it affects expression of $\mathrm{Na} / \mathrm{K}$-ATPase $\alpha 1$.
\end{abstract}

Key Words: blastocoel, gene expression, osmotic gradient, water channel

\section{Expressão relativa de mRNAs relacionados com o processo de cavitação em embriões bovinos produzidos in vivo e in vitro}

\begin{abstract}
RESUMO - Os objetivos neste trabalho foram identificar e avaliar possíveis diferenças na expressão gênica de transcritos de Aquaporina e ATPases- $\mathrm{Na} / \mathrm{K}$ presentes em embriões produzidos in vivo e in vitro. Para cada grupo, 15 blastocistos distribuídos em três conjuntos foram utilizados para a extração do RNA, seguida da amplificação e da transcrição reversa. Os DNAs complementares foram submetidos à reação em cadeia da enzima polimerase em tempo real, utilizando-se o gene GAPDH como controle endógeno. Não foi possível identificar transcritos de AQP1. A expressão relativa dos genes AQP3 $(1,33 \pm 0,78)$ e AQP11 $(2,00 \pm 1,42)$ não foi diferente em blastocistos produzidos in vitro e in vivo. O gene ATPase-Na/K $\alpha 1(2,25 \pm 1,07)$ encontrou-se sobrerregulado, enquanto o gene ATPase-Na/K $\beta 2(0,40 \pm 0,30)$ não diferiu entre os blastocistos produzidos in vitro e aqueles produzidos in vivo. Transcritos para o gene AQP1 não estão presentes em blastocistos bovinos. O sistema de cultivo in vitro não influencia a expressão dos genes AQP3, AQP11 e ATPase-Na/K $\beta 2$, porém altera a expressão do gene ATPase- $\mathrm{Na} / \mathrm{K} \alpha 1$.
\end{abstract}

Palavras-chave: blastocele, canal de água, expressão gênica, gradiente osmótico

\section{Introduction}

In cells, the intra- and extracellular environments are delimited by the plasma membrane, whose basic structure is the phospholipid bilayer where water can slowly cross over by simple diffusion. Moreover, water traffic through membrane can be facilitated by specialized protein membrane channels, named aquaporins (AQPs). Besides water, aquaporins can further transport small molecules such as glycerol, urea, and even ions. Multiple isoforms of this protein are differentially expressed in cells and in tissues, and their identification in specific periods of development can lead to a better understanding of each aquaporin role and their relationship with cell survival and development (Takata et al., 2004).

Blastocoel formation is essential for the preimplantation embryo development, and some aquaporins have been involved in this cavitation process (Barcroft et al., 2003; Edashige et al., 2000; Offenberg \& Thomsen, 2005). Water and small solutes can easily flow across membrane but the presence of these aquaporin channels may facilitate the flow of liquids and cryoprotectors. The role of aquaporin can be particularly important during 
embryo cryopreservation, contributing to a more efficient dehydration and rehydration and consequently to embryo survival post-cryopreservation. Moreover, blastocyst formation also involves an osmotic gradient establishment in the trophectoderm mediated by $\mathrm{Na}^{+} / \mathrm{K}^{+}$-ATPases that increases water flow from aquaporins channels to blastocoel. This fluid retention is essential for inner cell mass (ICM) and trophectoderm differentiation (Goossens et al., 2007; Madan et al., 2007). Embryo development involves the well coordinated expression of several genes and modifications in the physiological pattern might be related to failure in blastocoel expansion and/or reexpansion, for example, after cryopreservation procedures. Gene expression analyses have become an important tool to indirectly evaluate embryo quality, providing data about molecular response under certain environment or culture systems. Analysis of transcripts levels in embryos produced in vivo and in vitro has been used to identify regular gene expression patterns and to provide information for improving in vitro culture conditions (Goossens et al., 2007; Warzych et al., 2007). However, the role of AQPs and ATPases in cavitation process has not been properly addressed yet. Despite the advances in in vitro embryo production during the last years, the proportion of embryos that are able to develop until the blastocyst stage rarely is higher than $40 \%$ (reviewed by Neves et al, 2010). These results could be related to differences in gene expression patterns between in vivo and in vitro produced embryos. Therefore, the aims of this study were to identify and to analyze possible differences in relative expression of genes associated to blastocoel formation between in vivo and in vitro produced embryos.

\section{Material and Methods}

The experiment was carried out from February 2007 to December 2008. Holstein cows used for follicle aspiration (in vitro embryos) and superovulation protocols (in vivo embryos) had regular reproductive cycles and a body condition score of $2.77 \pm 0.64$ (classified according to Edmonson et al., 1989), at an average age of $5.38 \pm 1.50$ years.

For in vitro embryo production, oocytes were recovered from Holstein cows by transvaginal ultrasound guided follicle aspiration. Only 2-8 $\mathrm{mm}$ follicles were aspirated. The follicular fluid was placed in Petri dishes with TALP-Hepes media and cumulus-oocyte complexes (COCs) were identified and morphologically classified according to the number of granulosa cell layers and cytoplasm aspect (Viana et al., 2004). After selection, cumulus-oocyte complexes were in vitro matured in TCM-199 media (Nutricell, Campinas,
SP, Brazil), supplemented with $10 \%$ estrus cow serum and $20 \mu \mathrm{g} / \mathrm{mL} \mathrm{FSH}$, and incubated at $5 \% \mathrm{CO}_{2}, 38.5^{\circ} \mathrm{C}$ and $95 \%$ humidity for 24 hours.

In vitro fertilization and embryo culture were performed according to the methodology described by Camargo et al. (2005a). Matured oocytes were fertilized with $2 \times 10^{6}$ spermatozoa/mL for 20 hours in $5 \% \mathrm{CO}_{2}$, at $38.5^{\circ} \mathrm{C}$ and $95 \%$ humidity. Presumptive zygotes with their respective cumulus cells were cultured in CR2aa medium for eight days under the same conditions described for in vitro fertilization. Cleavage rate was evaluated at the moment of culture media replacement and blastocysts rated on day 7 of culture (D7). On the same day, embryos classified according to Stringfellow \& Seidel (1998) as blastocysts (BL) and expanded blastocysts (EB) of quality grades I or II were transferred to cryotubes and frozen in liquid nitrogen for subsequent RNA extraction.

For in vivo embryo production, cows were superovulated using a standard commercial protocol based in the control of luteal phase by the insertion of intravaginal progesterone releasing device $\left(\mathrm{CIDR}^{\circledR}\right.$, Pfizer, Hamilton, New Zeland), synchronization of follicular emergence by the administration of estradiol benzoate (RIC-BE - Syntex, Buenos Aires, Argentina) and induction of multiple ovulations by the administration of follicle stimulating hormone (FSH Pluset $^{\circledR}$, Callier, Barcelona, Spain). A total of 350 to 400 IU of $\mathrm{FSH}$, adjusted according to animal weight and previous response from each donor, were diluted in $10 \mathrm{~mL}$ sterile saline solution and delivered through eight IM decreasing doses. Estrus was detected after continuous visual observation and donors were inseminated 12 and 24 hours after estrus onset, using one dose of semen per insemination.

Embryos recovery was performed by intra-uterine flushing seven days after estrus. Embryo identification and classification were performed according to the same criteria used for the in vitro embryos. Blastocysts were transferred to cryotubes and frozen in liquid nitrogen for subsequent RNA extraction.

Total RNA was extracted from three 5-blastocyst pools by using the RNeasy Micro Kit (Qiagen GmbH, Hilden, Germany) according to the instructions by the manufacturer, and treated with DNAse. In order to obtain enough material to detect and quantify gene specific transcripts, mRNAs were amplified using the MessageAmp ${ }^{\mathrm{TM}}$ II aRNA Amplification Kit (Ambion, Austin, TX, USA) according to the instructions by the manufacturer.

The aRNA samples were reverse transcribed (RT) using the SuperScript III First-Stand Synthesis Supermix (Invitrogen, Carlsbad, CA, USA), also according to the instructions by the manufacturer. 
Complementary DNA (cDNA) samples obtained by reverse transcription were diluted in a concentration of 40ng/ $\mu 1$. Relative quantification was performed in triplicate using Real-Time PCR (ABI Prism 7300 Sequence Detection Systems, Applied Biosystems, Foster City, CA, USA) and reactions using a mixture of SYBR ${ }^{\circledR}$ Green PCR Master Mix (Applied Biosystems), $200 \mathrm{ng}$ of cDNA, nuclease-free water, and specific primers. Template cDNA was denatured at $95^{\circ} \mathrm{C}$ for 10 minutes followed by 40 cycles of $95^{\circ} \mathrm{C}$ for 15 seconds; gene-specific primer annealing temperature for 30 seconds (Table 1), and elongation at $60^{\circ} \mathrm{C}$ for 30 seconds. After each PCR run, a melting curve analysis was performed for each sample to confirm that only a single specific product was generated. Negative controls, comprised of the PCR reaction mix without nucleic acid, were also run with each group of samples. Expression of the GAPDH gene (variation coefficient $=5.06$ ) was used as endogenous reference. Calculations of relative quantification were performed by using the comparative $\mathrm{Ct}$ method, using the in vivo embryos as a reference control (value $=1$ ). Values of relative quantification of in vitro embryos are shown as $\mathrm{n}$-fold difference relative to the control. Relative gene expression analyses were performed using the software $\operatorname{REST}^{\circledR} 384$ and a pair-wise fixed reallocation randomization test (Pfaffl et al., 2002). Relative expression values are shown as mean \pm standard error (SEM) and differences $(\mathrm{P}<0.05)$ were considered significant. Amplicon sizes were confirmed by using $8 \%$ native acrylamide gel electrophoresis stained with silver nitrate.

\section{Results and Discussion}

Differences between embryos in vivo and in vitro produced have been shown to involve morphological and molecular aspects. Probably, such differences are induced by factors like oocyte quality, follicular environment, fertilization and embryo culture system. In vitro produced embryos usually present a darker color, earlier blastocoel formation without the proper compactation and lower cell number than in vivo produced embryos (reviewed by Camargo et al., 2006). Moreover, those embryos also show alterations in apoptosis frequency, cryopreservation tolerance gene expression and cell metabolism (Camargo et al., 2006; Knijn et al., 2002; Lonergan et al., 2006). Because in vitro produced embryos show alteration on blastocoel formation, this study was carried out in order to evaluate possible differences in expression of genes associated to AQP and $\mathrm{Na} / \mathrm{K}-\mathrm{ATP}$ ases proteins between embryos in vivo and in vitro produced.

Transcripts of AQP1 were not detected in embryos produced in vivo and in vitro. Expression of AQP1 gene has already been shown in different tissues and its role is to transport water through cell membrane (reviewed by Borgnia et al., 1999). In mice blastocysts, Offenberg \& Thomsen (2005) and Edashige et al. (2000) using the same primers but different mice strains did not found AQP1 transcripts, suggesting that AQP1 gene expression might differ among different strains. The current study has amplified mRNA in an attempt to ensure that minimal amounts of transcripts could be detected by Real-Time PCR, but it was also unable

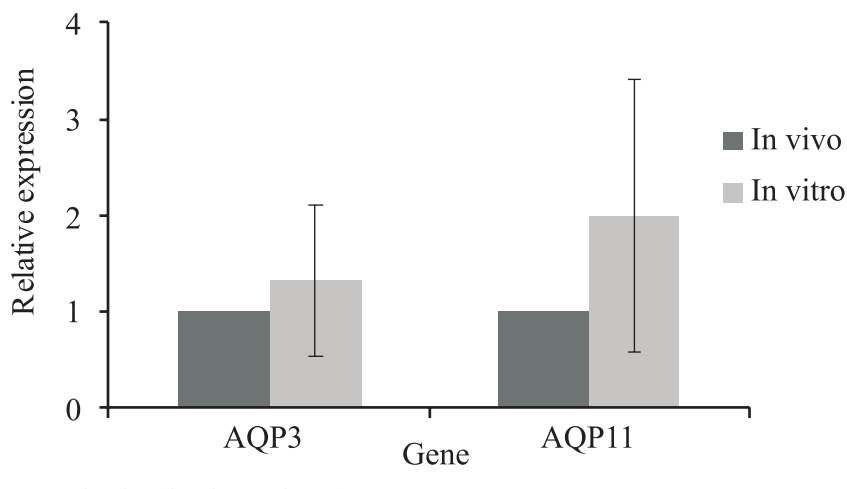

Control value (in vivo embryos) $=1$

Figure 1 - Relative gene expression of AQP3 and AQP11 transcripts in bovine blastocysts produced in vitro compared to those in vivo produced.

Table 1 - Description and characteristics of primer sequences used in real-time PCR for gene expression evaluation in bovine blastocysts

\begin{tabular}{|c|c|c|c|c|}
\hline Gene & Primer sequences $\left(5^{\prime}-3^{\prime}\right)$ & $\begin{array}{c}\text { Annealing } \\
\text { temperature }\left({ }^{\circ} \mathrm{C}\right)\end{array}$ & $\begin{array}{c}\text { Fragment } \\
\text { size (base pair) }\end{array}$ & $\begin{array}{c}\text { GenBank } \\
\text { accession number }\end{array}$ \\
\hline AQP 1 & F - GCACAATTTCCAGGACCACT & & & \\
\hline AQP3 & $\begin{array}{l}\mathrm{F} \text { - ACCGATCTAGCCCCTCATCT } \\
\mathrm{R} \text { - CCAACTCCACCGACAGAATC }\end{array}$ & 52 & 136 & NM-001079794 \\
\hline AQP 11 & $\begin{array}{l}\mathrm{F} \text { - TGGCACTTTCACTGCATTTC } \\
\mathrm{R} \text { - CATCCAGCTTGACTGTCCTG }\end{array}$ & 52 & 208 & XM_587121 \\
\hline $\mathrm{Na} / \mathrm{K}$-ATPase $\beta 2$ & $\begin{array}{l}\mathrm{F} \text { - AACCGGGTCATCAGCTTCTA } \\
\mathrm{R} \text { - CCGTTTGCAGGGAACATAAC }\end{array}$ & 52 & 116 & NM_174677 \\
\hline GAPDH & $\begin{array}{l}\text { F - CAGGAGCACGAGAGGAAGAGTT } \\
\text { R - GGCCTTAGAGATGGAAACATGTG }\end{array}$ & 52 & 102 & NM_001034034 \\
\hline
\end{tabular}


to detect AQP1 transcript.Therefore, these data suggest that for Holstein embryos at blastocyst stage transcripts for AQP1 gene are absent or are present in undetectable levels. Further experiments would be necessary to define when this gene starts to be expressed during embryo/fetal development and whether its expression may also be absent in bovine embryo of other bovine breeds.

The relative expression of $\mathrm{AQP} 3$ and $\mathrm{AQP} 11$ transcripts of in vitro embryos were not different $(\mathrm{P}>0.05)$ from in vivo embryos (Figure 1).

Low viability after cryopreservation when compared to in vivo produced embryos (Dobrinsky, 2002; Goossens et al., 2007; Niemann \& Wrenzycki, 2000; Warzych et al., 2007, Lonergan \& Fair, 2008) and a lack or low AQP3 expression in such embryos could be a hypothesis for this low viability. Nevertheless, the result of the present study suggests that for fresh Holstein embryos, alterations on AQP3 may not be involved in their viability post-cryopreservation. However, it should be considered the influence that different in vitro culture environment may cause on gene expression. For instance, the absence of differences in AQP3 expression differs from the results of Camargo et al. (2005b), who observed that these transcripts were up-regulated in bovine blastocysts in vivo produced when compared to those in vitro produced. This inconsistency may be due to differences in the in vitro adopted culture systems, which could influence the gene expression. In the present study, embryos were subjected to higher $\mathrm{O}_{2}$ tension and to the presence of serum and somatic cells in the culture, differently from the conditions used by Camargo et al. (2005b).

The lack of differences between in vivo and in vitro produced embryos suggests that the level of AQP 11 transcripts is not influenced by the culture system. In a single previous study with AQP11 in embryos, carried out in mice, Offenberg \& Thomsen (2005) observed the presence of AQP11 transcripts from 2-cell to blastocyst stages, but not in oocytes, which indicates that transcription may only occur after genome activation at the 2 -cell stage in mice. In this study, only embryos at the blastocyst stage were evaluated. Because bovine genome activation occurs at about the 8-cell stage, further studies would be necessary to identify when transcription activation of this gene begins. AQP11 function is not well defined but it has been suggested that it plays a role in intracellular water transport and its disruption might alter organelle homeostasis (Nozaki et al., 2008). If so, AQP11 channels could be important to keep organelle viability after cryopreservation, when intracellular organelles are subjected to dehydration and to rehydration. Characterization of spatial and temporal AQP11 transcription should contribute to elucidate its role on water transport.

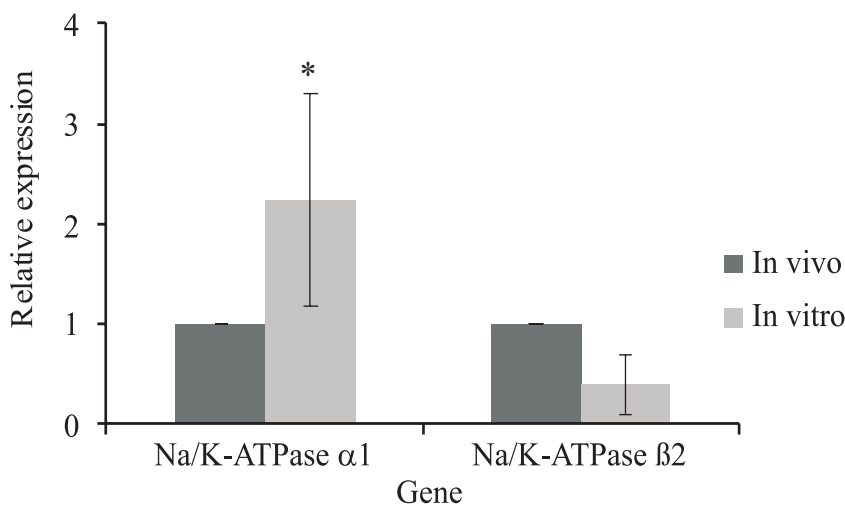

Control value (in vivo embryos) $=1$

Figure 2 - Relative gene expression of $\mathrm{Na} / \mathrm{K}$-ATPase $\alpha 1$ and $\mathrm{Na} /$ $\mathrm{K}$-ATPase $\beta 2$ transcripts in bovine blastocysts produced in vitro compared with produced in vivo $(* \mathrm{P}<0.05)$.

The relative expression of $\mathrm{Na} / \mathrm{K}$-ATPase $\alpha 1$ transcripts was up-regulated $(\mathrm{P}<0.05)$, while $\mathrm{Na} / \mathrm{K}$-ATPase $\beta 2$ transcripts were not different $(\mathrm{P}>0.05)$ in Holstein lastocysts produced in vitro when compared to those in vivo produced (Figure 2).

The up-regulation observed for $\mathrm{Na} / \mathrm{K}$-ATPase $\alpha 1$ may have some effects on embryo development and blastocoel formation, since this gene contains sites for ions and ATPs attachment and it is responsible for catalytic properties and enzyme transport (Blanco \& Mercer, 1998). Moreover, blastocyst cavitation may be regulated by a Na/K-ATPasegenerated trans-trophectoderm ion gradient that promotes the accumulation of water across the epithelium (Watson, 2004). Pre-implantation of bovine embryos in vitro cultured generally show a premature blastocoel formation. However, this earlier blastocyst formation has been associated to the presence of serum in the culture medium (Van Langendonckt et al., 1996; Holm et al., 2002), as performed by the current study. Thus, it can be speculated that an over-expression of $\mathrm{Na} / \mathrm{K}$-ATPase could be related to the presence of serum in culture medium, contributing to an early blastocoel formation. When bovine embryos were in vitro cultured with serumfree media, the expression of $\mathrm{Na} / \mathrm{K}$-ATPase $\alpha 1$ gene was down-regulated in comparison to in vivo embryos (Camargo et al., 2005b), which is the opposite to what was observed in the current study carried out with embryo cultured with serum. Both studies strengthen the previous speculation.

Regarding to $\mathrm{Na} / \mathrm{K}$-ATPase $\beta 2$, there have been no published works evaluating the relative expression of this gene in bovine embryos so far. This subunit is essential for the regular activity of the enzyme, and in vertebrate cells, it may act as a chaperone, stabilizing the correct folding of the $\mathrm{Na} / \mathrm{K}$-ATPase $\alpha 1$ (reviewed by Blanco \& Mercer, 1998). 
The current study, by considering the sensitivity method, shows that in vitro embryo production can alter the mRNA expression of one gene associated to blastocoel formation with no interference on expression of other genes. Taking into account the role of the product encoded by the gene, such alteration may be involved on the establishment of an osmotic gradient needed for formation of blastocoel. Data also provide more evidence of the absence of AQP1 transcripts at the bovine blastocyst stage. Overall, the present study shows that in vitro embryo culture can induce epigenetic modification in at least one gene associated to blastocyst formation.

\section{Conclusions}

Aquaporin 1 transcripts are not detectable in bovine blastocysts in vivo and in vitro produced and probably, their presence is not essential in the pre-implantation stage. The in vitro embryo production system affect expression of $\mathrm{Na} / \mathrm{K}$-ATPase al but not of other genes related to cavitation process. Further studies are required to establish the relationship among gene expression and blastocoels development potential of bovine embryos in vivo and in vitro produced.

\section{Acknowledgements}

The authors thank CNPq and Fapemig CVZ-1217/05 for financial support and Embrapa Dairy Cattle for technical support.

\section{References}

BARCROFT, L.C.; OFFENBERG, H.; THOMSEN, P. et al. Aquaporin proteins in murine trophectodermmediate transepithelial water movements during cavitation. Developmental Biology, v.256, p. $342-354,2003$

BLANCO, G.; MERCER, R.W. Isozymes of the Na-K-ATPase: heterogeneity in structure, diversity in function. American Journal of Physiolgy - Renal Physiology, v.275, p.633-650, 1998.

BORGNIA, M.; NIELSEN, S.; ENGEL, A. et al. Cellular and molecular biology of the Aquaporin water channels. Annual Reviews of Biochemistry, v.68, p.425-458, 1999.

CAMARGO, L.S.A.; VIANA, J.H.M.; FERREIRA, A.M. et al. Developmental competence of oocytes from prepubertal Bos indicus crossbred cattle. Animal Reproduction Science, v.85, p.53-59, 2005a.

CAMARGO, L.S.A.; POWELL, A.M.; VALE FILHO, V.R. et al. Comparison of gene expression in individual preimplantation bovine embryos produced by in vitro fertilization or somatic cell nuclear transfer. Reproduction, Fertility and Development, v. 17, p.487-496, 2005 b.

CAMARGO, L.S.A.; VIANA, J.H.M.; SÁ, W.F. et al. Factors influencing in vitro embryo production. Animal Reproduction, v.3, n.1, p.19-28, 2006

DOBRINSKY, J.R. Advancements in cryopreservation of domestic animal embryos. Theriogenology, v.57, p.285-302, 2002.
EDASHIGE, K.; SAKAMOTO, M.; KASAI, M. Expression of mRNAs of the aquaporin family in mouse oocytes and embryos. Cryobiology, v.40, p.171-175, 2000.

EDMONSON, A.J.; LEAN, I.J.; WEAVER, L.D. et al. A body condition scoring chat for Holstein dairy cows. Journal of Dairy Science, v.72, n.1, p.68-78, 1989 .

GOOSSENS, K.; VAN SOOM, A.; VAN POUCKE, M. et al. [2007]. Identification and expression analysis of genes associated with bovine blastocyst formation. BMC Developmental Biology, v.7, n.64, 2007. Disponível em: <http://www.biomedcentral.com/ 1471-213/7/64> Acesso em 25/8/2008

HOLM, P.; BOOTH, P.J.; CALLENSEN, H. Kinetics of early in vitro development of bovine in vivo - and in vitro- derived zygotes produced and/or cultured in chemically defined or serum containing media. Reproduction, v.123, p.553-565, 2002.

KNIJN, H.M.; WRENZYCKI, C.; HENDRIKSEN, P.J.M. et al. Effects of oocyte maturation regimen on the relative abundance of gene transcripts in bovine blastocysts derived in vitro or in vivo. Reproduction, v.124, p.365-375, 2002.

LONERGAN, P.; FAIR, T.; CORCORAN, D. et al. Effect of culture environment on gene expression and developmental characteristics in IVF-derived embryos. Theriogenology, v.65, p.137-152, 2006.

LONERGAN, P.; FAIR, T. In vitro-produced bovine embryos - Dealing with the warts. Theriogenology, v.69, n.1, p.17-22, 2008.

MADAN, P.; ROSE, K.; WATSON, A.J. Na/K-ATPase a1 subunit expression is required for blastocyst formation and normal assembly of trophectoderm tight junction-associated proteins. Journal of Biological Chemistry, v.282, n.16, p.12127-12134, 2007.

NEVES, J.P.; MIRANDA, K.L.; TORTORELLA, R.D. Progresso científico em reprodução na primeira década do século XXI. Revista Brasileira de Zootecnia, v.39, p.414-421, 2010 (supl. especial)

NIEMANN, H.; WRENZYCKI, C. Alterations of expression of developmentally important genes in preimplantation bovine embryos by in vitro culture conditions: implications for subsequent development. Theriogenology, v.53, p.21-34, 2000.

NOZAKI, K.; ISHII, D.; ISHIBASHI, K. Intracellular aquaporins: clues for intracellular water transport? European Journal of Phisyology (Pflügers Archiv), v.456, p.701-707, 2008.

OFFENRBERG, H.; THOMSEN, P.D. Functional challenge affects aquaporin mRNA abundance in mouse blastocysts. Molecular Reproduction and Development, v.71, p.422-430, 2005.

PFAFFL, M.W.; HORGAN, G.W.; DEMPFLE, L. Relative expression software tool $\left(\mathrm{REST}^{\odot}\right)$ for group-wise comparison and statistical analysis of relative expression results in real-time PCR. Nucleic Acids Research, v.30, n.9, e36, 2002.

STRINGFELlOW, D.A.; SEIDEL, S.M. Manual da Sociedade Internacional de Transferência de Embriões. 3.ed. Savoy: IETS, 1998. p.83-88.

TAKATA, K.; MATSUZAKI, T.; TAJIKA, Y. Aquaporins: water channel proteins of the cell membrane. Progress in Histochemistry and Cytochemistry, v.39, p.1-83, 2004.

VAN LANGENDONCKT, A.; AUQUIER, P.; DONNAY, I. et al. Acceleration of in vitro bovine embryo development in the presence of calf serum. Theriogenology, v.45, p.194, 1996 (abstract).

VIANA, J.H.M.; CAMARGO, L.S.A.; FERREIRA, A.M. et al. Short intervals between ultrasonographically guided follicle aspiration improve oocyte quality but do not prevent establishment of dominant follicles in the Gir breed (Bos indicus) of cattle. Animal Reproduction Science, v.84, n.1-2, p.1-12, 2004.

WARZYCH, E.; WRENZYCKI, C.; PEIPPO, J. et al. Maturation medium supplements affect transcript level of apoptosis and cell survival related genes in bovine blastocysts produced in vitro. Molecular Reproduction and Development, v.74, p.280-289, 2007.

WATSON, A.J.; NATALE, D.R.; BARCROFT, L.C. Molecular regulation of blastocyst formation. Animal Reproduction Science, v.82-83, p.583-592, 2004. 